\title{
Education and debate
}

\section{The performance of doctors. I: Professionalism and self regulation in a changing world}

Donald Irvine

This is the first of two articles. The second will be published next week

General Medical Council, London W1N 6JE

Donald Irvine president

BMJ 1997;314:1540-2
The performance of doctors embraces attitudes to practice, knowledge, and skills. It is the outward and visible expression of our professionalism. In general, people think highly of the medical profession in Britain; rising expectations are a mark of our success. Nevertheless, self regulation, on which our professional independence and self respect depend, cannot be taken for granted. Sympathetic critics such as lay people, sociologists, and doctors reflect a wider public perception that we seem reluctant to assure doctors' competence and protect patients from poor practice. There are also criticisms that we are not addressing the widespread dissatisfaction with the attitude of some doctors, including their paternalism and poor communication with both patients and colleagues, and are failing to make self regulation demonstrably effective and responsive. ${ }^{1-12}$

These criticisms, if not dealt with, could seriously damage public trust. They provide ammunition for people who oppose professional self regulation on the grounds that, where doctors' and patients' interests conflict, doctors' interests will invariably come first. Greater external control of the profession is their prescription.

In this article, and another to follow, I propose a modern expression of medical professionalism, founded on sound self regulation, that should bring the public's and the profession's interests together successfully.

\section{The changing world}

Our professionalism is shaped by the context in which we work. First and foremost, medical knowledge and skill have expanded at an unprecedented rate. This, together with the revolution in information technology, has huge implications for the profession. Can we, for example, maintain medicine as a distinctive entity in the face of growing subspecialisation? Can we adapt to careers that may not last a lifetime without reorientation and retraining?

People know more about health matters because they have independent access to clinical information and because their interest has been stimulated by media attention. More patients want an open relationship with their doctors: they want to be well informed and involved in decisions about their care.

Doctors are no longer alone in the clinical management of patients. Multiprofessional teamwork, the philosophy behind modern shared care, has to be

\section{Summary points}

Patients and doctors have a common interest in effective medical professionalism

Professional independence is a privilege, not a right

Professional independence cannot be assured without competent self regulation

A new agreement between medicine and society is needed

reconciled with the personal nature of the doctorpatient relationship.

Modern healthcare is complex to manage. A structured managerial framework, more accountability, and overt rationing now exist in the NHS. Many doctors are unhappy at the impact these developments have on their ability to practise in their own way. Yet the public expects doctors to help make the system work well.

Doctors' attitudes are also changing. For example, more doctors attach as much importance to the quality of their lives outside medicine as to their medical work. ${ }^{13}$ Part time practice has become more common for both men and women. Such developments have major implications for continuity of care and the organisation of medical work..$^{14}$

The effects of these changes are both exciting and bewildering. We delight in the successes of medicineand at times oversell it. Many doctors, though, feel alienated and undervalued. ${ }^{14}$ And the sheer complexity and pace of modern medicine is itself stressful.

To retain our independence, and reasonable control over our affairs, our professionalism must be capable of adapting to change.

\section{The importance of independence}

Medical professionalism rests on three pillars which together constitute the basis of our independence- or autonomy: expertise, ethics, and service. Expertise derives from a body of knowledge and skills whose utility is constantly invigorated by the results of research. Ethical behaviour flows from a unique 
combination of values and standards. Service embodies a vocational commitment to put patients first.

Independence gives individual doctors clinical freedom and the profession collectively the authority to decide about standards of professional practice and education, the organisation of medical work, and discipline. Furthermore, independence gives doctors that self respect which motivates them to perform well. ${ }^{15}$ Patients rely on an independent medical profession for authoritative advocacy on behalf of individuals and where the state or big business may engage in activities that threaten health (M Stacy, second international conference on medical registration, Melbourne, 1996). Equally, a profession with a strong sense of ethical duty makes an important contribution to a "civic society."

Our independence rests on three claims: firstly, that there is such an unusual degree of knowledge and skill involved in medical work that non-professionals are not equipped to evaluate or regulate it ${ }^{16}$; secondly, that doctors are responsible-they may be trusted to work conscientiously, without supervision; and, thirdly, that the profession itself may be trusted to undertake the proper regulatory action when individuals do not perform competently or ethically.

\section{Professional self regulation}

Professional self regulation underpins the concept of an "independent profession." It is a privilege given by the state through parliament. The Medical Act of 1858 established the statutory framework, including the General Medical Council. The Merrison committee said in 1975 that the GMC has to "assure itself that those admitted to the register are competent and to remove those practitioners unfit to practise. The maintenance of a register of the competent is fundamental to the regulation of a profession."15

The universities are accountable to the GMC for basic medical education, and the royal colleges determine standards of practice and education in their specialties. The Specialist Training Authority and the Joint Committee on Postgraduate Training for General Practice certificate the completion of training for entry to a specialty or general practice. Specialist certification leads to specialist registration with the GMC.

Professional self regulation is one element in the complicated relationship between the medical profession and society. For example, doctors working for the NHS are also accountable as employees and contractors. In a web of complex regulatory arrangements some tension is not only inevitable but healthy.

For self regulation, and therefore professional independence, to continue, patients must feel able to trust their doctors and society must feel able to trust the collective medical profession. We must become more transparently accountable for our performance and show, in ways that the public can understand and relate to, that self regulation really works.

With this recognition, a wider vision is now emerging. We are beginning to see professional self regulation as a dynamic continuum starting with the individual doctor and extending through the clinical team and local peer networks to the professional standards bodies (fig 1). It needs to be seen by doctors as positive and helpful, part of continuing education,

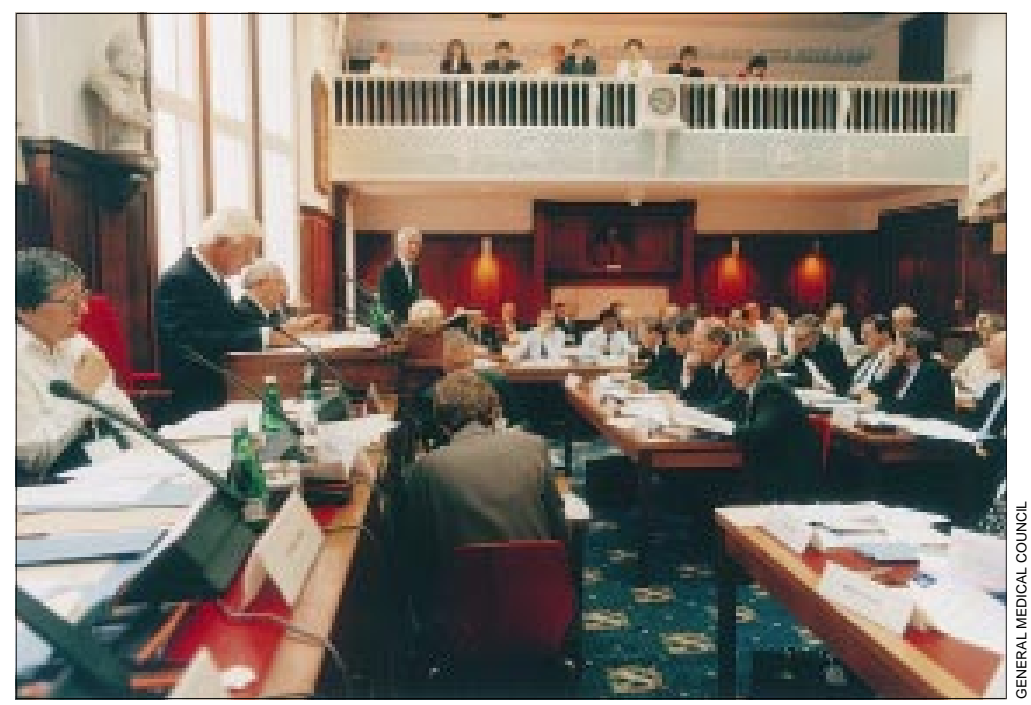

The GMC at work

personal professional development, and quality assurance of practice.

\section{Important principles}

\section{Values and standards}

Clearly enunciated values and standards are the foundation of effective self regulation. In 1995 a national conference considered the profession's core values, such as commitment, caring, competence, and integrity ${ }^{17}$; the BMA is taking this initiative further. In the same year the GMC published Duties of a Doctor, in which, for the first time, the principles of good medical practice were described. $^{18}$ Doctors and the public have reacted positively, showing how important it is that the profession indicates what individual doctors should do and what the public can expect of them.

Tomorrow's Doctors (1993) signalled the GMC's new approach to undergraduate medical education. ${ }^{19}$ The medical schools have gone to work on this with a real will. The New Doctor, published this year, reflects the GMC's determination to transform the preregistration year into an enjoyable and worthwhile experience. ${ }^{20}$

\section{A quality assured system}

To show that self regulation is effective and efficient we need to test the system against explicit criteria and standards, requiring hard evidence of compliance. The box shows some illustrative attributes and criteria. The GMC, for its part, will use such an approach to assure and improve the quality of its own performance.

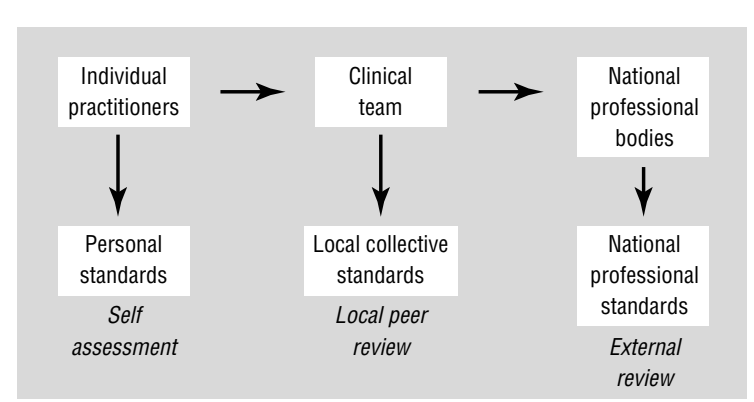

Fig 1 Maintaining good practice; the continuum of self regulation 


\section{Assuring quality in self regulated medical practice}

Purpose and values-Well defined values, functions, responsibilities, and strategic direction Performance-Evidence of competent management, good leadership, operational criteria and standards, good systems and data, effective performance monitoring, and feedback

Consistency-Evidence of thoroughness, fairness, and a systematic approach

Effectiveness or efficiency-Evaluation of the impact of procedures; evidence that the organisation is efficient and achieves good value for money Accountability-Responsibilities and lines of accountability well defined and understood; wherever possible the process of regulation made visible and results published; evidence of external audit Overall acceptability -Evidence that the overall performance and results of self regulation inspire the trust and confidence of the public, the medical profession, and doctors' employers

\section{Patients' involvement}

Modern self regulation is incomplete without involving people at all levels, to incorporate the patients' view of quality. To this end the GMC recently decided to increase its proportion of "lay" members to $25 \%$ and to appoint lay assessors to the teams that will assess doctors' performance under the new performance procedures.

\section{External peer review}

External peer review is an essential stimulus to effective performance and should become an integral part of self regulation. It applies equally to individuals, clinical teams, and institutions.

\section{Diversity with coordination}

Diversity characterises the British system of medical regulation. It means that each university medical school puts its stamp on basic medical education and each royal college determines standards of practice and education in its field. Each clinical team has its distinctive ethos. Diversity encourages new ideas, the development of different ways of achieving the same ends, and excellence in practice.

Without effective coordination, however, it is difficult to see the whole picture, how one part of the system relates to another, and whether the system as a whole works well. The best results will surely be achieved by setting individuality, with its evident strengths, within a framework of agreed goals and well coordinated partnerships, both locally and nationally. Then each partner will maintain a sense of ownership and achievement while contributing to a common purpose.

\section{The leadership role of teachers}

Role modelling is a powerful force in medicine. Marinker used the term "the hidden curriculum" to describe the effect of the professional attitudes and behaviour of clinical teachers on students and doctors in training. ${ }^{21}$ The everyday behaviour of clinical teachers is the living demonstration of their expertise, ethics, and commitment: their professionalism. What they do and how they do it matters as much as what they say-as in, for example, communicating with patients, students and colleagues; recognising the limits of their own practice; using clinical audit to improve their practice; applying formative peer appraisal for their own professional development; handling personal criticism; tackling poor performance in themselves and others; and caring for colleagues in difficulty.

The kind of leadership teachers give is critical to the quality of medical practice and education and to professional self regulation. The assessment of attitudes and interpersonal skills should therefore have a high priority in medical education.

\section{Towards a new agreement}

The time is ripe for a new agreement between medicine, the state, and society generally. It is our responsibility to see that professional practice is at one with people's expectations and to show that self regulation is effective. For its part, the state must give doctors the time needed to do a professional job for patients and to maintain standards of practice using modern methods. The proper resourcing of good medical practice-including medical education-must become an agreed given of good quality health care. With such an approach, we can be confident that our strengthened professionalism will keep the public's respect and trust.

This paper is based on the George Haliburton Hume, Cohen, and Telford lectures given in Newcastle upon Tyne, Edinburgh, and Manchester, respectively.

1 Kennedy I. The unmasking of medicine. London: Granada, 1983.

2 The doctor's dilemma. The Times 1992 March 2:15.

3 Klein R. The state and the profession: the politics of the double bed. BMJ 1990;301:700-2.

4 Select Committee on the Parliamentary Commission for Administration. Report of the Health Service Ombudsman for 1995-96. London: Stationery Office, 1997.

5 Rosenthal MM. Promise and reality: professional self-regulation and problem colleagues. In: Lens P, van der Wal G, eds. Problem doctors: a conspiracy of silence. Amsterdam: JOS Press, 1997.

6 Stacey M. The GMC and professional accountability. Public Policy and Administration 1989;4:12-27.

7 Stacey M. Regulating British medicine: the General Medical Council. Chichester: Wiley, 1992.

8 Rosenthal MM. The incompetent doctor: behind closed doors. Buckingham: Open University Press, 1995

9 Allsop J, Mulcahey L. Regulating medical work:formal and informal controls. Buckingham: Open University Press, 1996.

10 Smith R. Profile of the GMC: the day of judgment comes closer. BMJ 1989;298:1241-4.

11 Lock S. Regulating doctors. BMJ 1989;299:137-8.

12 Armstrong D. Medicine as a profession: times of change. BMJ 1990;301:691-3.

13 British Medical Association. Core values for the medical profession in the 21st century: survey report. London: BMA, 1995.

14 Allen I. Committed but critical: an examination of young doctors'views of their core values. London: BMA, 1997.

15 Committee of Inquiry into the Regulation of the Medical Profession. Report. London: HMSO, 1975. (Cmnd 6018; Merrison Committee report.)

16 Freidson E. Profession of medicine: a study of the sociology of applied knowledge. London: University of Chicago Press, 1988.

17 Core Values Conference. Core values for the medical profession in the 21 st century. London: BMA, 1995.

18 General Medical Council. Duties of a doctor: good medical practice. London: GMC, 1995.

19 General Medical Council. Tomorrow's doctors: recommendations on undergraduate medical education. London: GMC, 1993.

20 General Medical Council. The new doctor: recommendations on general clinical training. London: GMC, 1997.

21 Marinker M. Medical education and human values. $J$ R Coll Gen Pract 1974;24:83-94. 


\title{
Health in China
}

\section{From Mao to market reform}

\author{
Therese Hesketh, Wei Xing Zhu
}

\section{Summary}

After the Liberation by Mao Ze Dong's Communist army in 1949, China experienced massive social and economic change. The dramatic reductions in mortality and morbidity of the next two decades were brought about through improvements in socioeconomic conditions, an emphasis on prevention, and almost universal access to basic health care. The economic mismanagement of the Great Leap Forward brought about a temporary reversal in these positive trends. During the Cultural Revolution there was a sustained attack on the privileged position of the medical profession. Most city doctors were sent to work in the countryside, where they trained over a million barefoot doctors. Deng Xiao Ping's radical economic reforms of the late 1970 s replaced the socialist system with a market economy. Although average incomes have increased, the gap between rich and poor has widened.

\section{Problems "of vast importance"}

"Chinese problems, even if they affect no one outside China, are of vast importance since the Chinese constitute a quarter of the human race.... All the world will be vitally affected by the development of Chinese affairs ... during the next two centuries." These were Bertrand Russell's reflections after a visit to China in 1921. ${ }^{1}$ The Chinese still make up nearly a quarter of the world's population, over three times the population of the whole European Union and, as Russell predicted, China has become a major world influence. In the health field China has given us traditional Chinese medicine (a sophisticated discipline when Europeans were in the dark ages) tai chi, qi gong, barefoot doctors, the primary healthcare model for Alma Ata; the list goes on. China's experience in the past few decades also illustrates how twists and turns in politics directly affect the health of the people, so some understanding of recent history is essential to an understanding of the country today.

\section{Mao Ze Dong}

The China that Russell visited was a country ruled by warlords, racked by poverty and disease, and ripe for the birth of the Communist party. There followed a civil war for the control of China between the Communists and the Nationalists. In 1949 Mao Ze Dong's army was victorious, but what the Communists had won was a country devastated by years of war: poverty, malnutrition, and endemic disease existed on a huge scale, and the industrial base was in ruins. The infant mortality rate was estimated to be more than 250/1000.

Mao responded to the daunting task ahead by introducing massive social and economic change. Millennia of social tradition were swept away with the birth of the commune. This replaced the family unit, taking care of employment, food supply, child care, education, and health. Basic health care and preventive services
This is the first in a series of five articles on changing aspects of health care in China

\section{Centre for}

International Child

Health, London

WC1 N1EH

Therese Hesketh, research fellow

Health Unlimited, London SE1 9NT Wei Xing Zhu, programme manager, East Asia

Correspondence to: Dr Hesketh.

BMJ 1997;314:1543-5
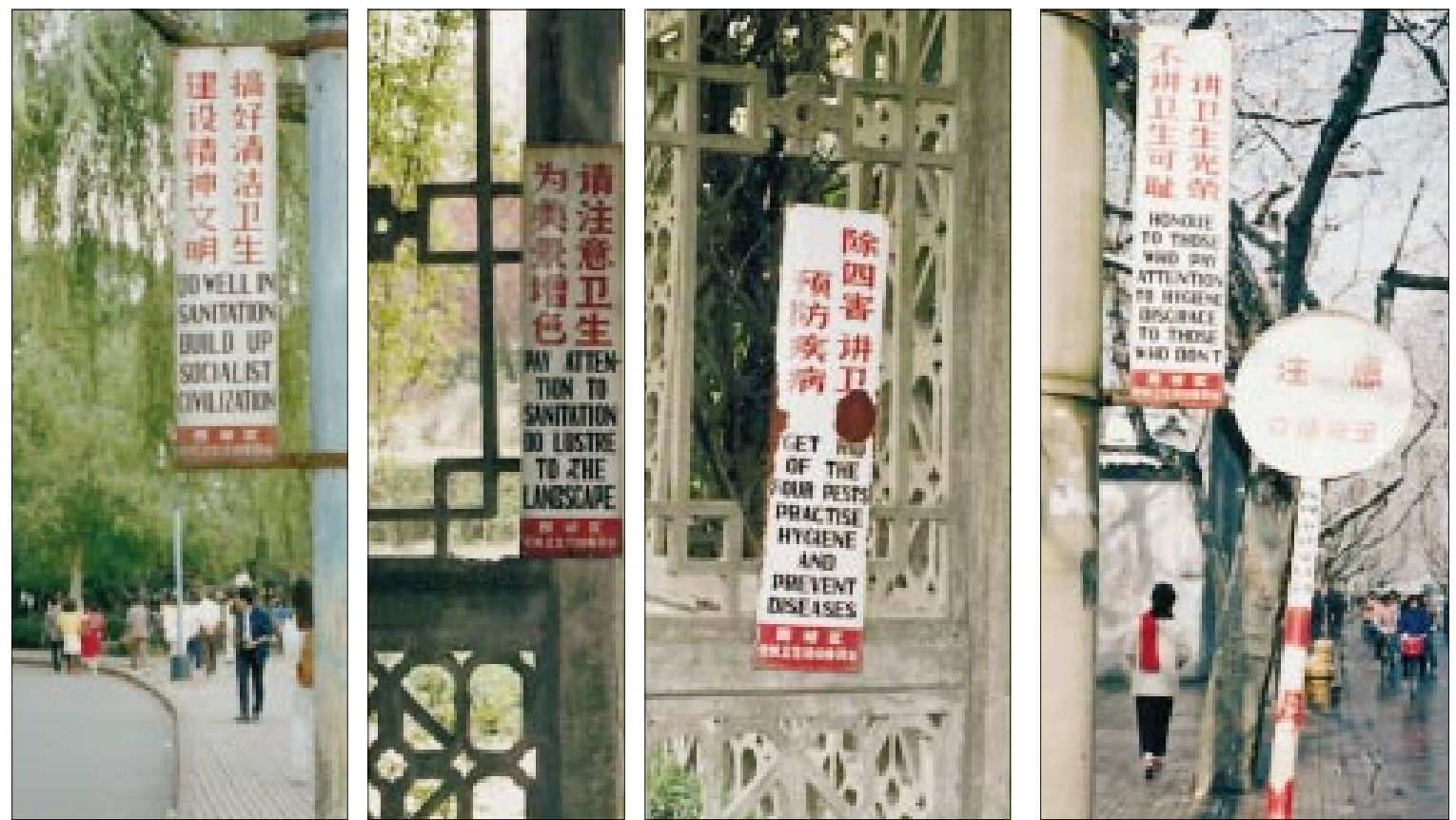

Public health education notices in Hangzhou. Health education notices are common in China, but they rarely appear in English 


\section{Guidelines for organising health care}

Four basic guidelines for the organisation of health care were announced at the First National Health Congress in 1950:

- Medicine should serve the workers, peasants, and soldiers

- Preventive medicine should take precedence over therapeutic medicine

- Traditional Chinese medicine should be integrated with Western scientific medicine

- Health work should be combined with mass

movements

were provided to everyone as part of the cooperative medical system.

This almost universal access to health care is one factor explaining the reductions in mortality and morbidity seen during the 1950 s and '60s. However, more important factors were stability after decades of war, the improvement in socioeconomic conditions, and the emphasis placed on prevention. ${ }^{2}$ Massive immunisation campaigns were carried out, brothels were closed, and campaigns against opium use were run. The Great Patriotic Health Campaigns mobilised the masses in tasks aimed at improving nutrition, sanitation, and water quality and attacking certain diseases. The anti-schistosomiasis campaign included organising teams to lance snails with sharpened chopsticks. The Four Pests Campaign aimed to eliminate flies, mosquitoes, rats, and sparrows. Sparrows were targeted because they ate grain. For days and nights people shouted and banged saucepan lids until the birds fell dead with exhaustion. But as a result the insects that would have been eaten by the birds now devoured the grain instead.

Eccentric as much of this sounds, the results were remarkable. A number of infectious diseases such as schistosomiasis, sexually transmitted diseases, leprosy, and plague were virtually eradicated, in the short term at least, though some are now returning.

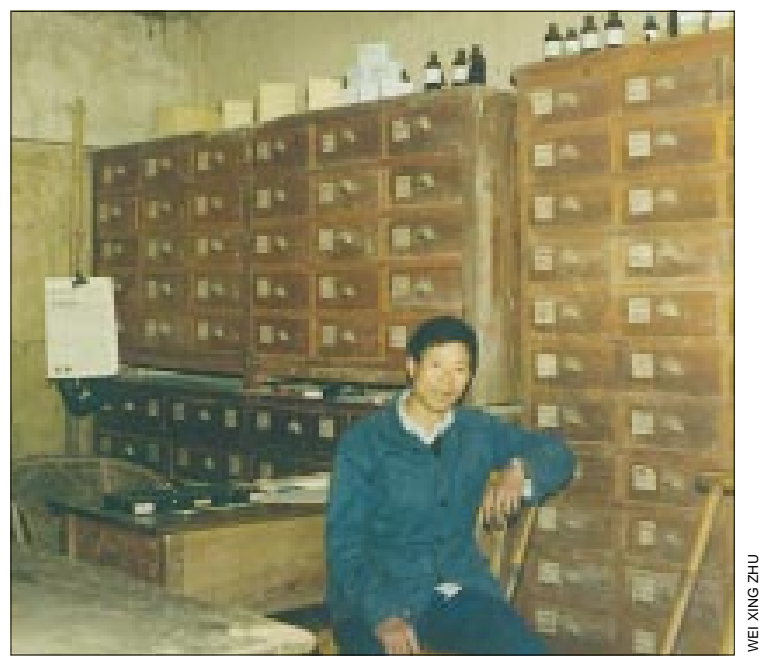

Village doctor's clinic. The drawers contain traditional Chinese herbal remedies

\section{The Great Leap Forward, 1958-60}

During the 1950s China was isolated by the Western powers, the Soviet Union being China's only ally. (It was with the help of Russian expertise that medical schools and hospitals were established.) Mao felt increasingly that he needed to prove the strength of the Communist system by expanding its industrial base.

Peasants were abruptly diverted from agricultural work to other tasks such as irrigation schemes and the new rural industries. As a result, in some areas crops were left to rot because it was no one's responsibility to harvest them. Ludicrous production targets were set, with disastrous consequences. To meet the grain targets farmers were urged to overfarm the land, which ruined the soil. To meet steel production targets, peasants were encouraged to set up backyard steel furnaces. Cooking pots, redundant in those days of communal eating, were melted down. The results of all this economic and agricultural mismanagement were disastrous. Estimates for the number who starved to death vary between 20 and 50 million. Infant mortality rose to over $300 / 1000$.

\section{Facts about China}

Population (1995): 1210000000

Infant mortality rate: $37 / 1000$

Maternal mortality: 50/100 000

Annual number of births: 22000000

Gross national product per capita: $\$ 470$

Life expectancy: 70 years

Adult literacy rate: $81 \%$

\section{The Cultural Revolution, 1966-76}

The Cultural Revolution was to bring further disruption. Political struggles in the senior echelons of the Communist party made Mao vulnerable and led him to intensify his dictatorial rule. Policy reversals were abrupt and had to be implemented without question or adaptation.

Mao launched an onslaught on the privileged position of the medical establishment. Medical schools and universities closed, as did specialist departments in hospitals. Many professionals, including doctors, were persecuted and tortured by the Red Guards, the anarchic groups of young people, who rampaged through the streets destroying anything representing the Four Olds: old customs, old ideas, old culture, and old habits.

It became compulsory for virtually all medical graduates to work in the countryside, usually for years at a time. Some worked as village doctors and trained locals to be barefoot doctors, while other simply worked the land. The more senior doctors were often allocated the most menial tasks-for example, the most experienced paediatric cardiac surgeon in China was sent to plant rice for seven years.

But some good came of all this. Over a million barefoot doctors were trained, and although some doctors are bitter about their treatment, and the prolonged separation from loved ones, many value the experience they gained of peasant life. The Chinese were keen that the image portrayed to the outside world at this time was a positive one: barefoot doctors, growing medicinal herbs, and providing care to the 
community at very low cost. ${ }^{2}$ The few examples of excellence became a model for the world and were cited at the Alma Ata conference. But this was all an integral part of the communal society and thus in many ways inappropriate for other developing countries.

When the medical schools reopened in 1972 the training was politicised, selection of students was related to political attitude, course length was arbitrary, and there was an emphasis on manual labour and Mao Ze Dong's thought. It was 1977 before standard five year medical training started again.

\section{The economic reforms}

Mao Ze Dong's death in 1976 brought an end to the Cultural Revolution. The power vacuum was filled by Deng Xiao Ping. He realised that two decades of economic stagnation meant that reform was essential to China's future survival and growth. The socialist system was replaced by a market system which essentially allows more rapid economic growth at the whim of market forces while accepting less equality. The communes were dismantled, and families could sell surplus produce at the newly opened free markets. The result was a doubling of agricultural output in five years, and the per capita income of the peasants increased by $10-12 \%$ a year. ${ }^{3}$

With the open door policy of 1982 foreign investment accelerated the process of growth. Economic growth is now running at $10 \%$ a year. ${ }^{4}$ Average incomes have increased but the gap between rich and poor has widened, with high inflation, especially for basic commodities, eroding purchasing power.

In health care the reforms have brought about crucial changes in the way that health is financed and organised. Some of the issues raised by the new market in health care will be discussed in the next article.

\footnotetext{
1 Sidel R, Sidel VW. The health of China. Boston, MA: Beacon Press, 1982

Taylor CE, Parker RC, Zheng DL Public health policies and strategies in

China. In: Holland WW, Knox S, Detels R, eds. Oxford textbook of public health medicine. Oxford: Oxford University Press, 1991.

3 Schell O. To get rich is glorious-China in the 1980s. New York: Mentor Pantheon, 1985.

4 Financial summary. Far Eastern Economic Review 1997 January 16:68.
}

\section{Socioeconomic determinants of health The contribution of nutrition to inequalities in health}

W Philip T James, Michael Nelson, Ann Ralph, Suzi Leather

\section{Summary}

Social class differences in health are seen at all ages, with lower socioeconomic groups having greater incidence of premature and low birthweight babies, heart disease, stroke, and some cancers in adults. Risk factors including lack of breast feeding, smoking, physical inactivity, obesity, hypertension, and poor diet are clustered in the lower socioeconomic groups. The diet of the lower socioeconomic groups provides cheap energy from foods such as meat products, full cream milk, fats, sugars, preserves, potatoes, and cereals but has little intake of vegetables, fruit, and wholewheat bread. This type of diet is lower in essential nutrients such as calcium, iron, magnesium, folate, and vitamin $\mathrm{C}$ than that of the higher socioeconomic groups. New nutritional knowledge on the protective role of antioxidants and other dietary factors suggests that there is scope for enormous health gain if a diet rich in vegetables, fruit, unrefined cereal, fish, and small quantities of quality vegetable oils could be more accessible to poor people.

\section{Introduction}

The poorer health of people in the lower socioeconomic groups in Britain is now well recognised (table 1), ${ }^{1}$ but its origins are complex. Diet has been considered a possible factor, but this is often seen as unlikely because most of the classic nutritional deficiencies are rare in Britain. Modern nutritional research into the pathophysiological basis of a variety of diseases has presented a new perspective, as shown in table 2. Many of the risk factors are clear, but the dietary contributors are just emerging. Physical activity is included because it determines total dietary intake, affects food choice, and has an independent metabolic effect.

Underlying most of these conditions are genetic factors which probably do not cluster in the lower socioeconomic groups, but any environmental disadvantage will have an impact on people who are genetically vulnerable. Excess smoking is a direct contributor to the clustered pattern of diseases-it operates partly through diet, influencing food choice adversely and reducing the dietary contribution to the antioxidant and DNA repair capacity of the body. Table 2 shows the importance of dietary quality and physical inactivity in promoting the wide range of preventable conditions affecting poor people. A high intake of vegetables, fruit, and fish with modest amounts of appropriate fats and limited intakes of foods and drinks rich in fats, salt, and sugars seems, with sustained physical activity and non-smoking, to be capable of promoting substantial health gains.

\section{Dietary and activity patterns}

The annual national food survey of 7000 British households shows that, compared with the highest income group (A), low income groups D and E2 consume more milk (but less semiskimmed milk), meat and meat products (of which more is higher fat meat products), fats, sugar and preserves, potatoes, and cereals. ${ }^{3}$ They consume fewer fresh vegetables, fruit, and higher fibre products such as brown and wholewheat
This is the last in a series of eight articles edited by Richard Wilkinson

Rowett Research Institute, Bucksburn, Aberdeen AB21 9SB W Philip T James, director Ann Ralph, research nutritionist

Department of Nutrition and Dietetics, King's College London, London W8 7AH Michael Nelson, senior lecturer in nutrition

National Food Alliance, London EC2A 2BH

Suzi Leather, consultant to the Food Poverty Network

Correspondence to: Dr Ralph.

BMJ 1997;314:1545-9 
Table 1 Observed prevalence of disease and risk factors within social class, in men and women of all ages. ${ }^{1}$ Values are percentage of population; blood pressure is given as mean values

Social class

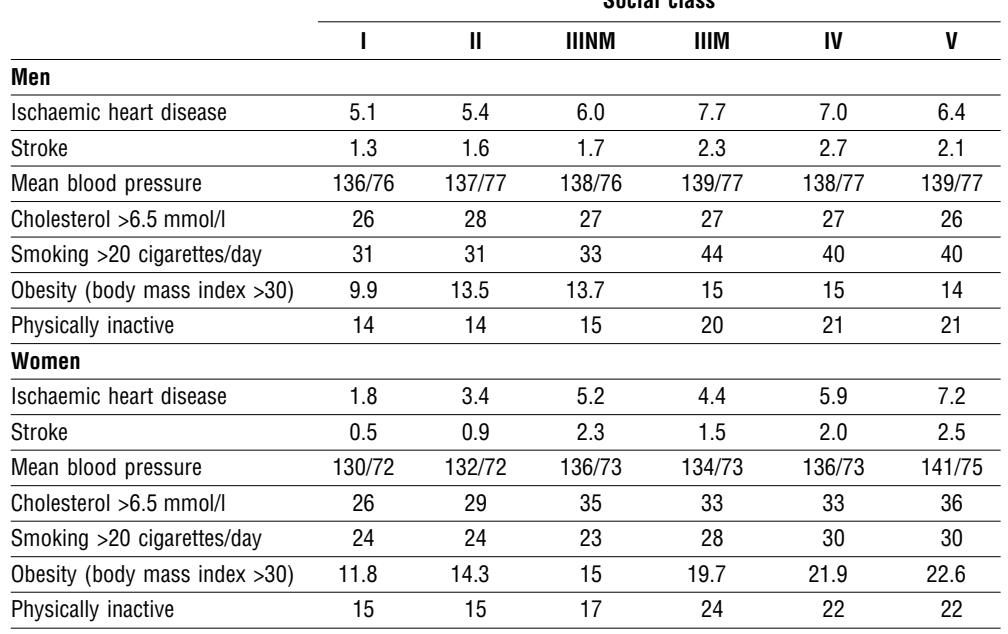

bread. Thus, the intake of nutrients as a percentage of the reference nutrient intake (the level that prevents $97.5 \%$ of the population from developing a classic deficiency) is lower in groups D and E2 for all nutrients, and markedly so for calcium, iron, magnesium, folate (and other B vitamins), and especially vitamin C (181\% for group A $v 118 \%$ for D and E2). Although some of these values are above $100 \%$ of the reference nutrient intake, this measure does not relate to newer knowledge on the protective role of nutrients as set out in table 2.
Over the past 15 years, food consumption and energy intakes have fallen, reflecting an increasingly sedentary lifestyle-but, as energy intakes decline, diets need to become more nutrient dense to compensate. The data in table 3 suggest that rich people have been better able to compensate than poor people. Moreover, there is a growing disparity in the diet between rich and poor. For every item, the changes between 1980 and 1995 have been worse for groups D and E2 and, except for vitamin $\mathrm{C}$ intake, the differences between groups $\mathrm{A}$ and $\mathrm{D}$ and $\mathrm{E} 2$ are greater now than 15 years ago, whether intake is expressed in ounces and grams or in terms of energy density (amount per 1000 $\mathrm{kcal} / 4184 \mathrm{~kJ}){ }^{3}$

\section{The poverty gradient and the poverty trap}

Even within the groups D and E2 there is a consumption gradient. Low income households with earners (group D) report lower levels of home purchases than households without an earner, dependent mainly on income support (E2). This difference is not explained by more food being obtained away from home by group D. The loss of benefits associated with moving off income support (such as free school meals) probably pushes group $\mathrm{D}$ households into the poverty trap. ${ }^{4}$ When food spending is very restricted, as for the $20 \%$ of income support claimants with compulsory deductions for rent or fuel, their diet is far below the reference nutrient intake for iron, calcium, dietary fibre, folate, and vitamin $\mathrm{C}$; it is lower still for smokers. ${ }^{5}$

Table 2 Excess disease rates in lower socioeconomic classes and their relation to diet in Britain

\begin{tabular}{|c|c|c|}
\hline & Risk factors & Dietary contributors \\
\hline \multicolumn{3}{|l|}{ Excess disease } \\
\hline Anaemia of pregnancy & Low iron; folate status & $\begin{array}{l}\text { Low intake of vegetables and fruit; low intake of meat; physical } \\
\text { inactivity }\end{array}$ \\
\hline Premature delivery & Lower folate; lack of n-3 fatty acids & Low intake of vegetables, fruit, and appropriate oils and fish \\
\hline Low birthweight or disproportion & $\begin{array}{l}\text { Adolescent pregnancy; lower folate; lack of } n-3 \text { fatty } \\
\text { acids; low weight gain in pregnancy ; smoking }\end{array}$ & Low intake of vegetables, fruit, and possibly trans fatty acids \\
\hline Anaemia in children and adults & Iron; folate; vitamin C and B-12 deficiency & $\begin{array}{l}\text { Possibly premature use of cows' milk; low intake of vegetables } \\
\text { and fruit; low intake of meat; diet low in nutrients, with low } \\
\text { intake linked to physical inactivity }\end{array}$ \\
\hline Dental disease & Low fluoride content of drinking water & Sweet snacks and drinks between meals \\
\hline Eczema/asthma & Parental smoking; air pollution & Low breastfeeding rates \\
\hline Insulin dependent diabetes mellitus & Viral infections & Low breastfeeding rates \\
\hline Obesity in childhood and adults & $\begin{array}{l}\text { Poor recreational facilities; intense traffic; excessive } \\
\text { television watching }\end{array}$ & Physical inactivity; energy dense ( high fat) diets \\
\hline Hypertension & Processed foods; low birthweight; adult weight gain & $\begin{array}{l}\text { Salty, energy dense foods with high sodium and low potassium, } \\
\text { magnesium, and calcium content; alcohol; low intake of } \\
\text { vegetables and fruit; inactivity }\end{array}$ \\
\hline \multicolumn{3}{|l|}{ Lipid abnormalities } \\
\hline High cholesterol & Excess weight gain & Excess dairy fats and some (hydrogenated) vegetable oils \\
\hline $\begin{array}{l}\text { Low high density lipoprotein or high } \\
\text { triglycerides }\end{array}$ & Excess weight gain & Physical inactivity; energy dense diets; low intake of fish \\
\hline Non-insulin dependent diabetes & Excess weight gain & Physical inactivity; energy dense diets \\
\hline Coronary artery disease & $\begin{array}{l}\text { Hypertension; lipid abnormalities; smoking; low folate } \\
\text { and antioxidants }\end{array}$ & $\begin{array}{l}\text { Salty, energy dense foods with high sodium and low potassium, } \\
\text { magnesium, calcium; alcohol; poor intake of vegetables, fruit } \\
\text { and fish; low activity }\end{array}$ \\
\hline Peripheral vascular disease & Smoking; low folate; lipid abnormalities & Poor intake of vegetables and fruit and possibly fish \\
\hline Cerebrovascular disease & Hypertension; low folate; high cholesterol & $\begin{array}{l}\text { Salty, energy dense foods high in sodium and low in } \\
\text { magnesium, calcium, potassium; alcohol; low vegetable and fruit }\end{array}$ \\
\hline $\begin{array}{l}\text { Cancers: lung, stomach, oropharyngeal, } \\
\text { oesophagus }\end{array}$ & Smoking with excess alcohol intake & Low intake of vegetables and fruit \\
\hline Cataracts & - & Low intake of vegetables and fruit \\
\hline Bone disease in elderly people & $\begin{array}{l}\text { Vitamin D deficiency; confined living and travel } \\
\text { opportunities }\end{array}$ & Physical inactivity, calcium poor diet \\
\hline
\end{tabular}




\section{Food expenditure}

Households in the bottom tenth of the income distribution spend on average $29 \%$ of their disposable income on food (after allowance for housing costs); those in the top tenth spend 18\% (fig 1). In families with children, expenditure on food per person in the bottom fifth of income is extraordinarily low (£1.64/person/day in lone parent families). Low socioeconomic groups, however, buy more efficiently than high income households (fig 2): the bottom tenth spends far less on alcohol (£1.85/person/week $v$ $£ 7.73$ in the top tenth) and sweets (£0.46 v £0.68). ${ }^{6}$ But these efficiencies lead to the purchase of foods richer in energy (high in fat and sugar) to satisfy hunger, which are much cheaper per unit of energy than foods rich in protective nutrients (like fruits and vegetables). ${ }^{7}$ The purchase of healthy options within mainstream eating patterns is likely to increase the food bill by $6-13 \%{ }^{8}$

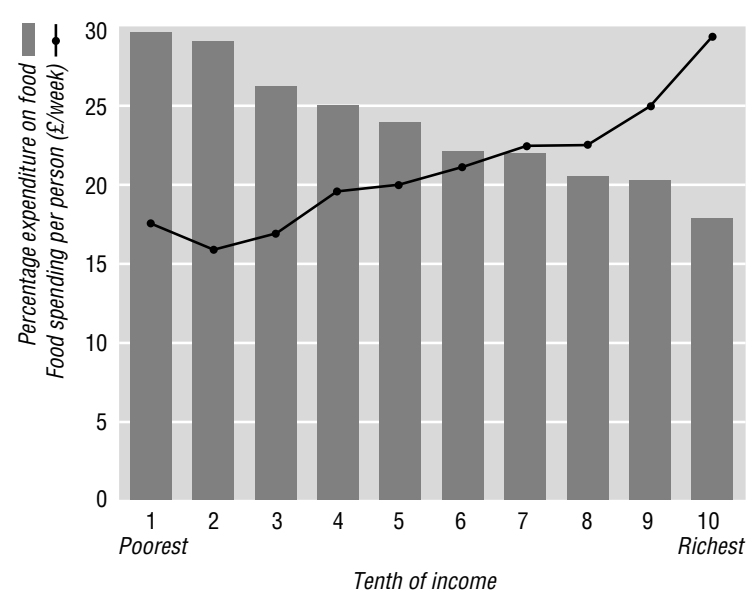

Fig 1 Percentage of household spending on food after allowance for housing costs and amount spent per person per week, by tenth of income $^{6}$

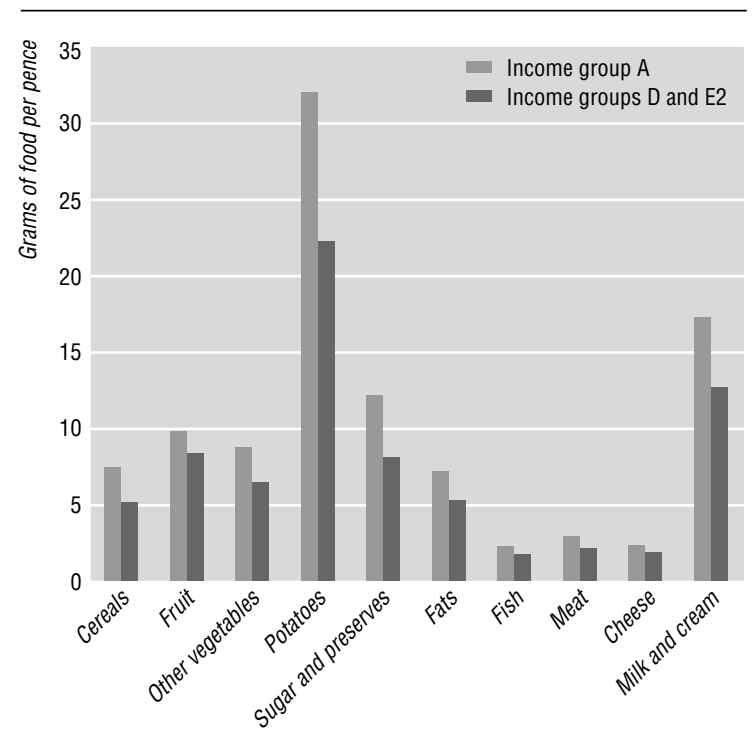

Fig 2 Spending efficiency (grams of food/pence), by income group, $1994^{2}$
Table 3 Comparison of food consumption and of nutrient intake or dietary density (per $1000 \mathrm{kcal} / 4184 \mathrm{~kJ}$ ) in high (A) and low (D and E2) income groups (from national food survey, $\left.1980-95^{3}\right)$

\begin{tabular}{|c|c|c|c|c|c|c|}
\hline \multirow[b]{2}{*}{ Income group } & \multicolumn{3}{|c|}{ Consumption level } & \multicolumn{3}{|c|}{ Density } \\
\hline & 1980 & 1995 & Difference & 1980 & 1995 & Difference \\
\hline \multicolumn{7}{|c|}{ Food (ounces per person per week) } \\
\hline \multicolumn{7}{|c|}{ Total fresh vegetables: } \\
\hline A & 31.4 & 27.5 & -3.9 & 14.7 & 17.6 & 2.9 \\
\hline $\mathrm{D}$ and $\mathrm{E} 2$ & 30.2 & 21.8 & -8.4 & 12.9 & 11.9 & -1.0 \\
\hline Difference & -1.2 & -5.7 & & -1.8 & -5.7 & \\
\hline \multicolumn{7}{|l|}{ Total fruit: } \\
\hline A & 38.7 & 45.3 & 6.6 & 18.1 & 29.0 & 10.9 \\
\hline $\mathrm{D}$ and $\mathrm{E} 2$ & 25.1 & 27.4 & 2.3 & 10.7 & 14.9 & 4.2 \\
\hline Difference & -13.6 & -17.9 & & -7.4 & -14.1 & \\
\hline \multicolumn{7}{|c|}{ Nutrient (amount per person per day) } \\
\hline \multicolumn{7}{|l|}{ Vitamin C (mg): } \\
\hline A & 71 & 60 & -9 & 33.2 & 38.5 & 5.3 \\
\hline $\mathrm{D}$ and $\mathrm{E} 2$ & 56 & 46 & -10 & 23.9 & 25.3 & 1.4 \\
\hline Difference & -15 & -14 & & -9.3 & -13.2 & \\
\hline \multicolumn{7}{|l|}{ Carotene $(\mu \mathrm{g})$ : } \\
\hline A & 2520 & 1700 & -820 & 1178 & 1090 & -88 \\
\hline $\mathrm{D}$ and $\mathrm{E} 2$ & 2440 & 1485 & -955 & 1034 & 809 & -225 \\
\hline Difference & -80 & -215 & & -144 & -281 & \\
\hline
\end{tabular}

\section{How can low income households have healthy diets?}

Low income not only restricts the ability to buy foods rich in protective nutrients but also limits the access to food retailers where healthy food can be purchased more cheaply. ${ }^{9}$ Few of the poorest families have access to a private car, but retailers have been moving out of town, and the total number of retail outlets has declined by $35 \%$ since 1980 . In only six years (1986-92), a quarter of greengrocers have closed. The spending efficiency in groups D and E2 is achieved in spite of often having to shop locally, where food can be $30 \%$ more expensive than in supermarkets. ${ }^{9}$

\section{Social class differences in diet throughout the life cycle}

The data in the national food survey ${ }^{3}$ are based mainly on food purchases. The picture of increasing social class inequality in diet is confirmed by surveys within special groups.

\section{Pregnancy and birth}

A poor diet in pregnancy, and smoking, leads to low birthweight babies. ${ }^{10} \mathrm{~A}$ diet low in folate not only predisposes to neural tube defects but also to lower birth weight and a shorter pregnancy. ${ }^{11}$ Lack of n-3 fatty acids from fish affects brain development, shortens pregnancy, reduces fetal weight gain, ${ }^{12}$ and limits placental function and fetal growth; this potential predisposes to adult diseases such as hypertension, diabetes, abdominal obesity, and coronary heart disease. ${ }^{10}$ The lower socioeconomic groups have greater rates of adolescent pregnancy, prematurity, and low birth weight.

\section{Infants}

Breast feeding is increasingly recognised as fundamental for long term health, but the breast feeding rate in the lowest socioeconomic groups is only half that in the highest socioeconomic groups. ${ }^{13}$ Numerous 
trophic factors, immune cells, polyamines, and long chain n-3 fatty acids that are present in breast milk promote growth and intestinal and brain development; breast feeding also avoids inappropriate dietary antigens-for example, from cows' milk and glutenthereby limiting the risk of intercurrent infections; diarrhoea (and necrotising colitis); chest infections; virally induced, insulin dependent diabetes; and atopic disease (see table 2) until at least adulthood. Preterm babies who are breast fed show higher IQs at age 8 (but social and educational components of parenting skills also link with maternal social class). It is now urgent to transform breast feeding rates in the low socioeconomic groups in Britain. Infants from lower socioeconomic groups have surprising rates of anaemia because of prematurity, with low iron stores and the inappropriate early feeding with whole cows' milk. $^{14}$

\section{Preschool children}

Inappropriate weaning fails to introduce vegetables and fruits within the critical period needed to establish dietary tastes; instead, early use of sweet and salty foods stimulates the primary taste buds, and persisting demands are amplified by parental reward systems using sweets, biscuits, cakes, soft drinks, sweetened yoghurt, and highly seasoned foods such as crisps. A diet high in these foods induces higher blood pressures within six months; dental erosions of primary teeth begin; and few fresh fruits or vegetables are then consumed..$^{15}$ Nutrient density is low, so intakes of micronutrients are modest. The effect of suboptimal vitamin and mineral intake on immune function, as shown in elderly people, may also explain the predisposition to recurrent infections of children from lower socioeconomic groups. ${ }^{16}$

\section{Schoolchildren and adolescents}

The poor diet of children from lower socioeconomic groups contributes to high rates of dental caries. The predisposition to anaemia in girls is amplified by inactivity, which reduces total food and therefore iron intakes and, with poor vitamin $\mathrm{C}$ intakes, iron absorption. Low intakes of available iron from haem sources (such as red meat) promote anaemia, and low intake of milk limits bone accretion; along with physical inactivity, this may enhance the later risk of osteoporosis. Salted foods high in phosphate and low in calcium and multiple daily intake of cola drinks with refined sugars limit calcium absorption or promote its excretion from bone, thereby amplifying the problem. Thus, the "junk food" habits of adolescents may have long term consequences in addition to atherogenesis.

High smoking rates and low antioxidant intakes also promote DNA damage in young men's sperm ${ }^{17}$ and may explain the enhanced risk of several cancers in their offspring. Adolescent girls entering pregnancy often have inadequate iron, folate, calcium, and n-3 fatty acids; their greater risk of premature, low birthweight babies (perhaps because they also are still growing) continues the intergenerational cycle of disease and social disadvantage.

\section{Adults and chronic disease}

Obesity, hypertension, non-insulin dependent diabetes, heart disease, stroke, and cancer were once known as the diseases of affluence but now particularly affect poor people in Britain. The links between a diet rich in saturated fat, which induces hypercholesterolaemia and coronary heart disease, have long been recognised, ${ }^{18}$ but the pathophysiology is now more complex. ${ }^{19}$ Low intakes of antioxidants, which are particularly evident in lower socioeconomic groups and in Scotland, Wales, and Northern Ireland, are now linked to atherogenesis, ${ }^{20}$ but homocysteinaemia induced by folate intakes below $400 \mu \mathrm{g}$ /day is also an independent risk factor for coronary heart disease, stroke, and peripheral vascular disease. The low intakes of folate, $\beta$ carotene, and vitamin $\mathrm{C}$ of the lower socioeconomic groups promote cardiovascular disease, but the trans fatty acids from hydrogenated margarines also contribute to thrombosis and atherogenesis ${ }^{21}$ and lower birth weights. ${ }^{22}$ The higher salt intakes of the lower socioeconomic groups amplify blood pressure levels and the risk of stroke, and poor fruit and vegetable consumption reduces potassium intake. The long chain polyunsaturated n-3 fatty acids; fish such as herring, sardines, and salmon; and nuts also limit sudden death from cardiac arrhythmia. ${ }^{23}$

\section{Chronic diseases of affluence}

Abdominal obesity, indicated by waist measurement, is more prevalent in women (but not men) in lower socioeconomic groups in Britain ${ }^{24}$; elsewhere-Sweden and the United States-there are clear social class differences in men and women..$^{25}$ This measure is associated with cortisol surges related to stress $^{26}$ and perhaps to fetally induced changes in the hypothalamic-pituitary-adrenal axis. ${ }^{27}$ Obesity is also associated with a greater risk of a range of other health problems, including diabetes, hyperlipidaemia, some cancers, breathlessness, menstrual disturbances, pregnancy complications, back pain and arthritis, skin disorder, and varicose veins. ${ }^{28}$ The causes of obesity are complex and include lack of exercise and a high fat, energy dense diet.

Mortality from all cancers is higher in lower socioeconomic groups, though breast cancer and bowel cancer are more prevalent in higher socioeconomic groups. ${ }^{29}$ While a diet high in fibre, vegetables, and fruit and low in meat and fat seems to be protective, other factors affecting risk are smoking, alcohol, and exercise. There is also clear evidence that survival from breast and colon cancer is positively related to socioeconomic status, but the relation to diet remains uncertain.

\section{Elderly people}

Old people at home are particularly vulnerable to a poor diet, and they are also at risk in hospitals and residential homes, where a lack of resources and staff time means that they do not always get well fed. Malnutrition leads to lower physical strength, greater inactivity, a higher risk of accidents, a weaker immune system, ${ }^{30}$ and osteoporosis. Poor vision, macular degeneration, and cataracts are all also now being linked to diets low in fruits and vegetables and antioxidants. ${ }^{31}$

\section{Conclusion}

Diet affects the health of socially disadvantaged people from the cradle to the grave. The social and economic reasons are complex, but the potential for 
health gain through improved diet is enormous. A poor quality diet, physical inactivity, and smoking are a lethal triad for the lower social classes, leading to an intergenerational spiral of ill health and handicap. Modern nutritional and sociological research is now providing a basis for targeted action to reverse this cycle.

1 Colhoun H, Prescott-Clarke P. Health survey for England 1994. London: HMSO, 1996.

2 Duthie GG, Arthur JR, Beattie JAG, Brown KM, Morrice, PC, Robertson JD, et al. Cigarette smoking, antioxidants, lipid peroxidation, and coronary heart disease. Ann N Y Acad Sci 1993;686:120-9.

3 Ministry of Agriculture, Fisheries, and Food. National food survey, 1980; 1995. London: HMSO, 1981; 1996.

4 Somerville SM, Rona RJ, Chinn S, Qureshi S. Family credit and uptake of school meals in primary school.J Public Health Med 1996;18:98-106.

5 Dowler E, Calvert C. Nutrition and diet in lone parent families in London. London: Centre for Human Nutrition, London School of Hygiene and Tropical Medicine, 1994.

6 Central Statistical Office. A report of the 1995-96 family expenditure survey. London: HMSO, 1996.

7 Leather S. The making of modern malnutrition. An overview of food poverty in the UK. London: Caroline Walker Trust, 1996.

8 Nelson M, Mayer AB, Manley P. The food budget. In: Bradshaw GH, ed. Budget standards for the United Kingdom. Aldershot: Avebury, 1993.

9 Piachaud D, Webb J. The price of food: missing out on mass consumption. STICERD, London 1996.

10 Barker DJP, ed. Fetal and infant origins of adult diseases. London: BMJ Books, 1992.

11 Scholl T, Hediger ML, Schall JI, Khoo G-S, Fischer RL. Dietary and serum folate: their influence on the outcome of pregnancy. Am J Clin Nutr 1996;63:520-5.

12 Olsen SF, Hansen HS, Secher NJ, Jensen B, Sandstrom B. Gestation length and birth weight in relation to intake of marine n-3 fatty acids. $\mathrm{Br}$ J Nutr 1995;73:397-404.

13 Mills A, Tyler H. Food and nutrient intakes of British infants aged 6-12 months. London: HMSO, 1992.
14 Royal College of Physicians, Faculty of Public Health Medicine. Promoting breastfeeding. Guidelines for Health Promotion 1995;41:1-11.

15 Gregory JR, Collins DL, Davies PSW, Hughes JM, Clarke PC. National diet and nutrition survey: children aged $1^{1 / 2}$ to $41 / 2$ years. $\mathrm{Vol} 1$. Report of the diet and nutrition survey. London: HMSO, 1995.

16 Chandra RK. Nutrition and the immune system. Proc Nutr Soc 1993;52:77-84.

17 Fraga CG, Motchink PA, Shigenaga MK, Helbock HJ, Jacob RA, Ames BN. Ascorbic acid protects against endogenous oxidative DNA damage in human sperm. Proc Natl Acad Sci USA 1991;88:1103-6.

18 Keys A, Anderson JT, Grande F. Serum cholesterol response to changes in the diet. III. Differences among individuals. Metabolism 1965;14:766-75.

19 Ross R. The pathogenesis of atherosclerosis-an update. $N$ Engl J Med 1986;314:488-500.

20 Scottish Office, Home and Health Department. The Scottish Diet. Report of a working party to the chief medical officer for Scotland. Edinburgh: The Scottish Office, Home and Health Department, 1993.

21 Mann GV. Metabolic consequences of dietary trans fatty acids. Lancet 1994;343:1268-71

22 Koletzko B. Trans fatty acids and the human infant. World Rev Nutr Diet 1994;75:82-5.

23 James WPT. Nutritional disorders affecting the heart. In: Julian DG, Camm AJ, Fox KM, Hall RJC, Poole-Wilson PA, eds. Diseases of the heart. 2nd ed. London: Saunders, 1996:1442-58.

24 Ford G, Ecob R, Hunt K, MacIntyre S, West P. Patterns of class inequality in health through the lifespan: class gradients at 15,35 and 55 years in the west of Scotland. Soc Sci Med 1994;39:1038-50.

25 Kuskowska-Wolk H, Bergstrom R. Trends in body mass index and prevalence of obesity in Swedish men 1980-1989. J Epidemiol Community Health 1993;47:103-8.

26 Bjorntorp P. Endocrine abnormalities of obesity. Metabolism Clinical and Experimental 1995;44 (suppl 3):21-23.

27 James WPT. Long-term fetal programming of body composition and longevity. Nutr Rev 1996;55:S31-43.

28 Scottish Intercollegiate Guidelines Network. Obesity in Scotland.Integrating prevention with weight management. Edinburgh: SIGN, 1996.

29 Sharp L, Finlayson AR, Black RJ. Cancer incidence and deprivation in Scotland. J Epidemiol Community Health 1995;49 (suppl 2):S78-80.

30 Chandra RK. Effect of vitamin and trace-element supplementation on immune responses and infection in elderly subjects. Lancet 1992;340:1124-7.

31 McLauchlan WR, Sanderson J, Williamson G. Antioxidants and the prevention of cataracts. Biochem Soc Trans 1995;23:257S

\section{A patient who changed my practice Always check the respiratory rate}

The young lad had been injured riding a motorbike "off road." He was complaining of lower chest pain and had tenderness suggestive of blunt injury but with no obviously fractured ribs. His pulse and blood pressure were normal but he was breathing at 40 per minute. A drip was put up and he was sent to have an $x$ ray examination.. While being transferred to the trolley his blood pressure dropped and he became unconscious. He was rushed back to the resuscitation room and what had seemed to be a controlled situation became an emergency.

Despite intravenous fluids and ventilation he remained hypotensive. The on call surgical registrar was called and examined his abdomen. "Nothing for us in there," was the verdict. He was transferred to intensive care where despite full resuscitative measures, he died that night. A necropsy showed a ruptured spleen and liver lacerations. He came in talking and died.

I was not involved in his treatment but his death shocked me. Trauma resuscitation was one of the hot topics and advanced trauma life support programmes were just beginning to be talked about. Although no courses had yet been run in the Britain, trauma scoring was starting to show promise, and the Royal College of Surgeons' report on 1000 trauma deaths was soon to be published. His death reinforced that it is the young who die from trauma, but also illustrated several other points, now thankfully much more widely recognised.

Young people will maintain normal blood pressure and even pulse rate until they suddenly decompensate; they are then almost impossible to resuscitate. Most importantly the respiratory rate is an accurate reflection of severity of illness.

Of the 16 physiological variables measured by the original trauma score, only three- -the Glasgow coma score, blood pressure, and respiratory rate, have a positive correlation with mortality. The next two years saw advanced trauma life support programmes start throughout Britain, the start of the major trauma outcome study, and a move towards centralising trauma care in larger departments with $x$ ray facilities in accident and emergency departments. Ultrasound and peritoneal lavage are now used rather than simple examination to evaluate abdominal trauma, and fewer young people die from treatable injuries.

I now always check the respiratory rate in patients with serious medical or surgical conditions, but while we have electronic means of measuring pulse, blood pressure, temperature, and oxygen saturation, respiratory rate is still calculated by eye and is still the most commonly omitted observation.

$\mathrm{P}$ Burdett-Smith, consultant in accident and emergency medicine, Liverpool

We welcome filler articles up to 600 words on topics such as A memorable patient, A paper that changed my practice, My most unfortunate mistake, or any other piece conveying instruction, pathos, or humour. If possible the article should be supplied on a disk. 